\title{
Implementasi Sistem Informasi Puskesmas Elektronik (SIMPUSTRONIK) dan Hubungan Dengan Pelayanan Kesehatan Ibu dan Anak (KIA) (Studi Perbandingan Implementasi di Puskesmas Sumberasih dan Puskesmas Paiton Kabupaten Probolinggo)
}

\author{
${ }^{1}$ Sunar Wibowo, SKM, 2Prof. Dr.Abdul Hakim, MSi, ${ }^{3}$ Dr. M. Makmur, MS \\ ${ }^{1}$ Dinas Kesehatan Kabupaten Probolinggo \\ ${ }^{2}$ Program Magister dan Doktor, Fakultas IImu Administrasi, Universitas Brawijaya \\ ${ }^{3}$ Program Magister dan Doktor, Fakultas IImu Administrasi, Universitas Brawijaya
}

\begin{abstract}
Abstrak
Puskesmas sebagai penyedia sarana pelayanan kesehatan dituntut untuk memberikan pelayanan kesehatan yang cepat, tepat dan akurat. Oleh karena itu, merupakan suatu keharusan bahwa puskesmas memanfaatkan kemajuan informasi teknologi dalam memenuhi tuntutan pelayanan tersebut. Dengan pendekatan kuantitatif positivitik untuk menjelaskan hipotesa penelitian guna menjawab faktor implementasi yang mendukung dan kemanfaatan SIMPUSTRONIK. Survey yang dilakukan kepada bidan sebagai pelaksana SIMPUSTRONIK di Puskesmas Paiton dan Puskesmas Sumberasih Kabupaten Probolinggo menghasilkan 3 indikator implementasi yang tidak mendukung keberhasilan implementasi SIMPUSTRONIK yaitu pembagian tugas dan wewenang, keikutsertaan pengguna dalam pengembangan implementasi dan keikutsertaan pengguna dalam evaluasi implementasi. Sedang indikator yang diteliti lainnya menunjukkan adanya hubungan. indikator implementasi tersebut berhubungan erat dengan kesiapan SDM (pengetahuan SDM) serta keterkaitan keikutseraan (partisipasi) implementor. Hampir semua responden menunjukkan bahwa implementasi SIMPUSTRONIK bermanfaat dan mendukung kegiatan mereka dalam pelayanan KIA, tetapi yang terbesar adalah kemanfaatan penemuan ibu hamil resiko tinggi yang dirujuk.
\end{abstract}

Kata kunci: Implementasi, Sistem Informasi Manajemen Puskesmas

\begin{abstract}
Public Health Center as a provider of health care facilities are required to provide health care fast, precise and accurate. Therefore, it is imperative that health centers utilizing advances in information technology to meet the demands of the service. Positivitik quantitative approach to explain the research hypothesis to answer the implementation factors that support and benefit SIMPUSTRONIK. The survey conducted by the midwife as executor SIMPUSTRONIK in health centers and health centers Sumberasih Paiton Probolinggo generate three indicators implementations that do not support the successful implementation of SIMPUSTRONIK namely the division of tasks and responsibilities, user participation in the development and implementation of user participation in the evaluation of the implementation. Other indicators are being studied showed no association. The implementation of the indicator is closely related to the readiness of HR (HR knowledge) and the linkages keikutseraan (participation) implementor. Almost all respondents indicated that the beneficial SIMPUSTRONIK implementation and support their activities in Mother and child services, but the biggest is the benefit of the discovery of high-risk pregnant women who were referred
\end{abstract}

Keywords: Implementation, Management Information Systems Health Center

\section{PENDAHULUAN}

Memperhatikan perkembangan teknologi informasi saat ini, maka pelayanan kesehatan seharusnya telah mempergunakan kemajuan teknologi informasi tersebut. Hal ini dikarenakan sistem informasi telah mempengaruhi segala segi kehidupan manusia, untuk itu sulit membayangkan layanan kesehatan tanpa

\footnotetext{
Alamat Korespondensi Penulis:

Sunar Wibowo

Email : wiwidyafisari@gmail.com

Alamat : Dinas Kesehatan Kabupaten Probolinggo

Jl. Panglima sudirman 403 Kraksaan Probolinggo
} Jawa Timur informasi modern, teknologi informasi dan komunikasi (ICT). Information Communication Technology (ICT) menawarkan peluang yang luar biasa dalam mengurangi kesalahan layanan kesehatan klinis, mendukung para profesional kesehatan, meningkatkan efisiensi layanan perawatan kesehatan dan bahkan meningkatkan kualitas layanan perawatan (2001). Badan Kesehatan Dunia (WHO) mendukung penerapan Teknologi Informasi dan Sistem Informasi di bidang pelayanan kesehatan untuk mencegah faktor kesalahan manusia.

Kohn (1999) mengatakan kesalahan medis menyebabkan antara 44.000 sampai 98.000 
kematian di Amerika setiap tahunnya. Untuk mengatasi hal tersebut organisasi pelayanan kesehatan memutuskan menggunakan aplikasi teknologi informasi, yaitu CPR (Computer-based Patient Record) untuk menurunkan kesalahan medis.

Puskesmas sebagai penyedia sarana pelayanan kesehatan dituntut untuk memberikan pelayanan kesehatan yang cepat, tepat dan akurat. Oleh karena itu, merupakan suatu keharusan bahwa puskesmas memanfaatkan kemajuan informasi teknologi dalam memenuhi tuntutan pelayanan tersebut.

Menurut Hatta (2011) sesuai kesepakatan rencana kerja yang disusun pada pertemuan 12 Desember 2003 di Jenewa, target untuk tahun 2015 yang harus dicapai Negara anggota World Summit on the Information Society (WSIS) termasuk Indonesia yaitu seluruh pusat kesehatan termasuk puskesmas serta rumah sakit sudah terhubungkan dengan teknologi informasi dan komunikasi.

Sejalan dengan perkembangan teknologi informasi dan upaya memenuhi kebutuhan informasi dalam sistem pelayanan kesehatan yang pro publik, sudah banyak pihak yang berusaha mengembangkan sistem informasi pelayanan kesehatan berbasis komputer. Pihak institusi pelayanan kesehatan memiliki kesempatan untuk memilih dan mengimplementasikan aplikasi komputer dan sistem penunjangnya yang komprehensif. Sarana pelayanan kesehatan sebagai penghasil data/informasi senantiasa memperhatikan masukan yang diberikan oleh tenaga kesehatan.

Penggunaan teknologi informasi untuk layanan kesehatan juga diterapkan di Pusat Kesehatan Masyarakat (Puskesmas). Berdasarkan Keputusan Menteri Kesehatan Nomor 128/Menkes/SK/II/2004 disebutkan bahwa Sistem Informasi Manjemen Puskesmas (SIMPUS) adalah suatu tatanan yang menyediakan informasi untuk membantu proses manajemen Puskesmas. Perkembangan Informasi dan Teknologi mempengaruhi juga Perkembangan SIMPUS yaitu dengan Pengembangan SIMPUSTRONIK.

Sistem Informasi Manajemen Puskesmas Elektronik (SIMPUSTRONIK) adalah nama aplikasi SIMPUS yang disediakan oleh Dinas Kesehatan Kabupaten Probolinggo yang diadopsi dari Dinas Kesehatan Kabupaten Ngawi dengan Fasilitator UNICEF (The United Nations Children's Fund).

Puskesmas di kabupaten Probolinggo belum sepenuhnya diharuskan melaksanakan
SIMPUSTRONIK, mengingat sumber daya dan situasi kondisi Puskesmas yang berbeda-beda, maka kebijakan yang mengharuskan Puskesmas melaksanakan SIMPUSTRONIK belum dilaksanakan, hanya sebagai himbauan.

Setelah berjalan selama 4 (empat) tahun, dari 29 (dua puluh sembilan) puskesmas yang telah diinstall SIMPUSTRONIK hanya ada di 5 (lima) Puskesmas, dimana Bidan Desa telah mengentry data melalui SIMPUSTRONIK. Dari ke 5 (lima) puskesmas tersebut terdapat 2 puskesmas yaitu puskesmas Sumberasih dan Puskesmas Paiton yang sejak awal menjadi daerah pilot project. Selain itu, menurut penulis keduanya memiliki karakteristik yang sama yaitu :

1. Keduanya merupakan Jenis puskesmas Rawat Inap;

2. Memiliki jumlah Desa wilayah kerja yang sama;

3. Kemampuan sarana dan prasarana yang dimiliki memiliki kesamaan

4. Memiliki wilayah kerja di daerah geografis pantai - dataran rendah

Untuk itu para pelaksana (Implementor) Simpustronik di Puskesmas Paiton dan Puskesmas Sumberasih ditetapkan sebagai responden penelitian. Selain menggambarkan kondisi secara umum para implementor, penelitian ini dimaksudkan menemukan faktorfaktor implementasi yang mendukung implementasi SIMPUSTRONIK di kedua puskesmas tersebut. Apabila benar, apakah implementasi SIMPUSTRONIK berpengaruh terhadap pelaksanaan program KIA di Puskesmas Paiton dan Puskesmas Sumberasih? Jika ada pengaruh implementasi SIMPUSTRONIK terhadap pelaksanaan program KIA maka apakah ada perbedaan implementasi SIMPUSTRONIK diantara kedua puskesmas tersebut, dikarenakan implementor yang berbeda?

\section{METODE PENELITIAN}

Pendekatan penelitian ini menggunakan metode kuantitatif positivitik yang digunakan untuk lebih menjelaskan hipotesa penelitian berbentuk pengujian, dengan data nominal atau kontinyu dan dipakai uji statistik dalam pengujiannya. (Wibowo, 2002: 4). Dilaksanakan survey untuk mendapatkan data primer dan sekunder, yang yang digunakan untuk bahan analisis atas permasalahan penelitian.

Penelitian ini telah menetapkan variabel dan indikator-indikatornya, untuk memperoleh data penelitian yang bisa lebih mendekati realita dan terukur. Indikator penelitian sangat membantu 
dalam jenis dan cara memperoleh data serta penentuan pertanyaan-pertanyaan kuisioner yang dibuat. Parameter, variabel dan indikator tersaji dalam tabel 1.

Pencarian indikator dilakukan dengan menuangkan dalam bentuk kuesioner. Sebelum kuesioner disebarkan ke responden terlebih dahulu dilakukan uji validitas dan realibilitas. Uji validitas dilakukan dengan metode pearson correlation. Sedangkan uji realibilitas menggunakan metode spearman brown correlation

Tabel1. parameter, Variabel dan indikator yang diteliti

\begin{tabular}{|c|c|c|c|}
\hline No & Parameter & Variabel & Indilkator \\
\hline \multirow{3}{*}{1} & \multirow{3}{*}{ Sumberdaya } & \multirow{3}{*}{ SDMimplementor } & pengalaman Implementor \\
\hline & & & Pembagian Tugas\& wewenang \\
\hline & & & Jumlahdan jenis fasilitas \\
\hline \multirow{4}{*}{2} & \multirow{4}{*}{ Komunikasi } & Kejelasan isi pesan & Kejelassn isi pesan yang dikomunikasikan \\
\hline & & Intensitas Sosialisasi & Frekuensisosialisssi \\
\hline & & \multirow{2}{*}{ Saranakomunikasi } & Saranayang digunakandalam komunikasi \\
\hline & & & Teknikdan metode yang digunakan \\
\hline \multirow{6}{*}{3} & \multirow{3}{*}{$\begin{array}{l}\text { Silap dan } \\
\text { Perilaku }\end{array}$} & Komitmen & Minatimplementor \\
\hline & & pemahamanatas program & Tingkat pemahaman implementor dalam melaksnakan program \\
\hline & & Komitmen & Komitmen dan semangat implementor \\
\hline & \multirow{3}{*}{ Struktur Birokras } & Koordinasi & TingkatKoordinasiantarimplementor \\
\hline & & silstandarissi prosedur & Tingkat perubahan jadwal kegiatan program \\
\hline & & kebijakan & Tingkat perubahan prosedur dan aturan pelakssnaan program \\
\hline \multirow{3}{*}{5} & & $\begin{array}{l}\text { Keterlibatan dalam tahap } \\
\text { perencenanan program }\end{array}$ & Tingkat keterlibatan target group dalam tahap perencanaan program \\
\hline & $\begin{array}{l}\text { Keterlibatan User } \\
\text { (Bidan) }\end{array}$ & $\begin{array}{l}\text { er Keterlibatani dalam tahap } \\
\text { pelaksanaan program }\end{array}$ & Tingkatketeribatan target group dalam tahap pelaksonaan program \\
\hline & & $\begin{array}{l}\text { Keterlibatan dalam tahap } \\
\text { pengawasan program }\end{array}$ & Tingkat keteribatan target group dalam tahap pengawassn program \\
\hline \multirow{3}{*}{6} & \multirow{3}{*}{$\begin{array}{l}\text { Tingkat Kineja } \\
\text { Implementasi } \\
\text { Program }\end{array}$} & \multirow{3}{*}{ Baik//idak Baik } & Tingkatkepatuhan target group terhadap aturan dan prosedur \\
\hline & & & Hasil nyata output(kemanfaatan) \\
\hline & & & Tingkat penerimaan program oleh target group \\
\hline \multirow{7}{*}{7} & \multirow{7}{*}{ Kemanfatan KIA } & \multirow{7}{*}{ Pessepsi pemanfaatan } & Bagibidan \\
\hline & & & Bgik4 \\
\hline & & & Bagi pesalinan nakes \\
\hline & & & bumilrestidinjuk \\
\hline & & & Kunjunganneonatus \\
\hline & & & Kunjungan Bayi \\
\hline & & & Cakupan BBLR Y yang ditangani \\
\hline
\end{tabular}

Analisa data dilakukan statistik diskriptif dan uji hipotesis. Deskriptif digunakan untuk mengetahui diskripsi umum tentang latar belakang responden yang terkait dengan perasalahan penelitian. Metode analisa statistik diskriptif yang digunakan adalah frekuensi dan distribusi.

Sementara uji hipotesis digunakan untuk menentukan adanya pengaruh atau tidak berpengaruh variabel dengan hasil analisa lapangan serta untuk membedakan kondisi pelaksanaan implementasi antara puskesmas paiton dan puskesmas sumberasih. Uji hipotesis dilakukan dengan menggunakan uji Chi Square dan uji T. Dengan menggunakan ketentuan daerah penolakan hipotesis seperti dibawah ini: - $\chi^{2}$ hit $>\chi^{2}$ tab $; d f=(k-1) *(b-1)$ atau Asym Sig. $>\alpha$ berarti $\mathrm{H}_{0}$ ditolak, sedangkan apabila $-\chi^{2}{ }_{\text {hit }} \leq \chi^{2}$ tab $; \mathrm{df}=(\mathrm{k}-1) *(\mathrm{~b}-1)$ atau Asym Sig. $\leq \alpha$ berarti $\mathrm{H}_{0}$ diterima.

Adapun derajat hubungan pengaruh keduanya dengan melihat hasil perhitungan contingency coefficient, dimana ditentukan derajat hungungan dengan kategori "tidak ada korelasi antara 2 variabel", "korelasi sangat lemah", "korelasi sedang", "korelasi kuat", "korelasi sangat kuat", dan "korelasi sempurna"

\section{Metode Pengumpulan Data}

Pengumpulan data dilakukan dengan mengirimkan kuesioner kepada responden dalam hal ini bidan sebagai implementor SIMPUSTRONIK di Puskesmas Paiton dan Puskesmas Sumberasih yang berisi pertanyaanpertanyaan berkaitan dengan parameter, variabel dan indikator dalam penelitian ini. Pemilihan ke 2 puskesmas didasarkan pada puskesmas tersebut sebagai Puskesmas Pilot Project saat pertama aplikasi SIMPUSTRONIK dipergunakan. Responden yang akan menjadi subyek penelitian ini adalah bidan sebagai implementor SIMPUSTRONIK di wilayah Desa Puskesmas Paiton 13 orang, dan Puskesmas Sumberasih 13 orang serta ditambah bidan yang bertugas di tiap puskesmas induk 4 orang sehingga didapat responden sebanyak 34 orang, tetapi 2 orang tidak mengembalikan quesioner dengan alasan yang tidak jelas, sehingga hanya 32 quesioner yang bisa diteliti.

\section{HASIL DAN PEMBAHASAN}

Hasil penelitian menunjukkan responden semua berjenis kelamin wanita dengan pendidikan D3, dimana kelompok usia responden menunjukkan hal yang berbalikan yaitu usia responden di Puskesmas Sumberasih didominasi mereka yang berusia dibawah 30 tahun $(47,06 \%)$, sedangkan di Puskesmas Paiton didominasi usia 40 tahun ke atas. (53,33\%). Tetapi secara Total usia responden didominasi oleh usia diatas 40 Tahun yaitu sebanyak 37,50\%.

Meskipun ke 2 puskesmas menjadi daerah pilot project tetapi secara individu di Puskesmas Sumberasih dalam menjalankan SIMPUSTRONIK dalam kurun waktu $>3$ tahun lebih banyak dari pada di Puskesmas Paiton. Tercatat sebanyak $88,2 \%$ responden dari Puskesmas Sumberasih telah melaksanakan implementasi SIMPUSTRONIK, hal ini berbeda dengan responden di Puskesmas Paiton karena semua responden telah melaksanakan SIMPUSTRONIK kurang dari 3 Tahun.

Demikian pula untuk pengenalan responden terhadap aplikasi komputer (pertama bisa 
menggunakan komputer), maka di Puskesmas Sumberasih telah menggunakan komputer sudah sejak sekolah sebanyak 9 responden (52,9\%), sudah setelah bekerja sebanyak 2 responden $(11,8 \%)$ dan sisanya baru menggunakan setelah aplikasi SIMPUSTRONIK dipergunakan sebanyak 6 responden (35,3\%), sedangkan responden di Puskesmas Paiton sebagian besar menyatakan baru setelah bekerja mengenal komputer sebanyak 8 responden (53,3\%), 4 responden $(26,7 \%)$ menggunakan setelah aplikasi SIMPUSTRONIK dipergunakan dan 3 responden (20\%) telah mengenal sejak masih sekolah.

Untuk mengetahui ada tidaknya pengaruh faktor-faktor implementasi dilakukanlah pengujian terhadap hipotesis-hipotesis dari setiap indikator dari masing-masing parameter implementasi yang telah ditetapkan yaitu: Sumber Daya, Komunikasi, Sikap dan Perilaku, Struktur Birokrasi dan Keikutsertaan Pengguna

Hasil perhitungan untuk variabel faktor-faktor implementasi terhadap baik dan dan tidak baiknya implementasi SIMPUSTRONIK didapatkan hasil sebagai berikut.

- Untuk Pengalaman implementor ada pengaruh terhadap baik dan tidak baiknya implementasi SIMPUSTRONIK. Hal ini dari hasil perhitungan diperoleh angka $\mathrm{X}^{2}=$ 2,577; asymp.sig $=0,108 \quad \alpha=0,05$ maka $\mathrm{H}_{0}$ ditolak atau $\mathrm{H}_{1}$ diterima. Adapun derajat korelasinya sedang (contingency coff = 0,273 )

- Untuk Pembagian tugas dan wewenang tidak ada pengaruh terhadap baik dan tidak baiknya implementasi SIMPUSTRONIK. Hal ini dari hasil perhitungan diperoleh angka $\mathrm{X}^{2}$ $=8,568$; asymp.sig =0,003 $\alpha=0,05$ maka $\mathrm{H}_{0}$ diterima atau $\mathrm{H}_{0}$ ditolak.

- Untuk fasiltas / sarana pendukung implementasi SIMPUSTRONIK ada pengaruh terhadap baik dan tidak baiknya implementasi SIMPUSTRONIK. Hal ini dari hasil perhitungan diperoleh angka $\mathrm{X}^{2}=$ 0,009; asymp.sig = 0,926 $\alpha=0,05$ maka $\mathrm{H}_{0}$ ditolak atau $\mathrm{H}_{1}$ diterima. Adapun derajat korelasinya sangat lemah (contingency coff $=0,15$ )

- Untuk tingkat penerimaan implementor setelah pelatihan / sosialisasii SIMPUSTRONIK ada pengaruh terhadap baik dan tidak baiknya implementasi SIMPUSTRONIK. Hal ini dari hasil perhitungan diperoleh angka $X^{2}=2,076$; asymp.sig $=0.150 \alpha=0,05$ maka $\mathrm{H}_{0}$ ditolak atau $\mathrm{H}_{1}$ diterima. Adapun derajat korelasinya sangat lemah (contingency coff $=0,247$ )

- Untuk jumlah frekuensi pertemuan/ sosialisasi implementasi SIMPUSTRONIK ada pengaruh terhadap baik dan tidak baiknya implementasi SIMPUSTRONIK. Hal ini dari hasil perhitungan diperoleh angka $X^{2}=$ 5,053; asymp.sig $=0,25 \quad \alpha=0,05$ maka $\mathrm{H}_{0}$ ditolak atau $\mathrm{H}_{1}$ diterima. Adapun derajat korelasinya sedang (contingency coff = $0,369)$

- Untuk sarana penginformasian implementasi SIMPUSTRONIK ada pengaruh terhadap baik dan tidak baiknya implementasi SIMPUSTRONIK. Hal ini dari hasil perhitungan diperoleh angka $\mathrm{X}^{2}=$ 1,499; asymp.sig = 0,221 $\alpha=0,05$ maka $\mathrm{H}_{0}$ ditolak atau $\mathrm{H}_{1}$ diterima. Adapun derajat korelasinya sangat lemah (contingency coff $=0,212$ )

Untuk metode penginformasian implementasi SIMPUSTRONIK ada pengaruh terhadap baik dan tidak baiknya implementasi SIMPUSTRONIK. Hal ini dari hasil perhitungan diperoleh angka $\mathrm{X}^{2}=$ 0,729; asymp.sig = 0,694 $\alpha=0,05$ maka $\mathrm{H}_{0}$ ditolak atau $\mathrm{H}_{1}$ diterima. Adapun derajat korelasinya sangat lemah (contingency coff $=0,149$ )

- Untuk minat implementor dalam implementasi SIMPUSTRONIK ada pengaruh terhadap baik dan tidak baiknya implementasi SIMPUSTRONIK. Hal ini dari hasil perhitungan diperoleh angka $X^{2}=$ 2,264; asymp.sig $=0,132 \alpha=0,05$ maka $\mathrm{H}_{0}$ ditolak atau $\mathrm{H}_{1}$ diterima. Adapun derajat korelasinya sedang (contingency coff = 0,257 )

- Untuk tingkat pemahaman implementor setelah sosialisasi / pelatihan implementasi SIMPUSTRONIK ada pengaruh terhadap baik dan tidak baiknya implementasi SIMPUSTRONIK. Hal ini dari hasil perhitungan diperoleh angka $X^{2}=1,460$; asymp.sig $=0,227 \alpha=0,05$ maka $\mathrm{H}_{0}$ ditolak atau $\mathrm{H}_{1}$ diterima. Adapun derajat korelasinya sangat lemah (contingency coff $=0,209$ )

- Untuk tingkat koordinasi antar implementor pada implementasi SIMPUSTRONIK ada pengaruh terhadap baik dan tidak baiknya implementasi SIMPUSTRONIK. Hal ini dari hasil perhitungan diperoleh angka $X^{2}=$ 3,128; asymp.sig = 0,077 $\alpha=0,05$ maka $\mathrm{H}_{0}$ ditolak atau $\mathrm{H}_{1}$ diterima. Adapun derajat 
korelasinya sedang (contingency coff = 0,298 )

- Untuk perubahan aturan atau perkembangan SIMPUSTRONIK terhadap implementasi SIMPUSTRONIK ada pengaruh terhadap baik dan tidak baiknya implementasi SIMPUSTRONIK. Hal ini dari hasil perhitungan diperoleh angka $\mathrm{X}^{2}=$ 3,680; asymp.sig =0,055 $\alpha=0,05$ maka $\mathrm{H}_{0}$ ditolak atau $\mathrm{H}_{1}$ diterima. Adapun derajat korelasinya sedang (contingency coff = 0,321 )

- Untuk keterlibatan pengguna dalam perencanaan implementasi SIMPUSTRONIK ada pengaruh terhadap baik dan tidak baiknya implementasi SIMPUSTRONIK. Hal ini dari hasil perhitungan diperoleh angka $\mathrm{X}^{2}$ $=0,734$; asymp.sig = 0,693 $\alpha=0,05$ maka $\mathrm{H}_{0}$ ditolak atau $\mathrm{H}_{1}$ diterima. Adapun derajat korelasinya sangat lemah (contingency coff $=0,150$ )

- Untuk keterlibatan pengguna dalam pengembangan implementasi SIMPUSTRONIK tidak ada pengaruh terhadap baik dan tidak baiknya implementasi SIMPUSTRONIK. Hal ini dari hasil perhitungan diperoleh angka $\mathrm{X}^{2}=$ 7,126; asymp.sig $=0,028 \quad \alpha=0,05$ maka $\mathrm{H}_{0}$ diditerima atau $\mathrm{H}_{1}$ ditolak.

- Untuk keterlibatan pengguna dalam evaluasi implementasi SIMPUSTRONIK tidak ada pengaruh terhadap baik dan tidak baiknya implementasi SIMPUSTRONIK. Hal ini dari hasil perhitungan diperoleh angka $X^{2}$ $=8,680$; asymp.sig $=0,013 \alpha=0,05$ maka $\mathrm{H}_{0}$ diditerima atau $\mathrm{H}_{1}$ ditolak.

Memperhatikan hasil tersebut diatas maka indikator implementasi yang berpengaruh terhadap implementasi SIMPUSTRONIK adalah: pengalaman implementor, fasiltas / sarana pendukung implementasi SIMPUSTRONIK, tingkat penerimaan implementor setelah pelatihan / sosialisasii SIMPUSTRONIK, jumlah frekuensi pertemuan / sosialisasi implementasi SIMPUSTRONIK, sarana penginformasian implementasi SIMPUSTRONIK, metode penginformasian implementasi SIMPUSTRONIK, minat implementor dalam implementasi SIMPUSTRONIK, tingkat pemahaman implementor setelah sosialisasi / pelatihan implementasi SIMPUSTRONIK, tingkat koordinasi antar implementor pada implementasi SIMPUSTRONIK, perubahan aturan atau perkembangan SIMPUSTRONIK, dan Untuk keterlibatan pengguna dalam perencanaan implementasi SIMPUSTRONIK, kesemuanya telah mendukungi dengan teori implementasi yang dikemukakan oleh Edward III, Hogwood\&gunn, Mater \&horn, Mazmanian \& seabatier, Grindle dengan derajat hubungan yang sangat lemah sampai kuat.

Memperhatikan hasil perhitungan dari koefisien kontingensi Fasilitas/sarana pendukung dan Keterlibatan pengguna dalam perencanaan implementasi SIMPUSTRONIK dengan kriteria hasil sangat lemah dapat dijelaskan sebagai berikut.

Pemberian fasilitas memang berpengaruh tetapi juga mendekati tidak berpengaruh. Hal ini bisa dijelaskan bahwa di lapangan para implementor akan berusaha sendiri untuk memenuhi kebutuhan sarana bagi implementasi SIMPUSTRONIK. Hal ini dibuktikan bahwa 53,1\% menyediakan hardware sendiri (milik pribadi) dan yang disediakan oleh layanan pemerintah hanya 40,6\%. Demikian untuk masalah pendanaan $84,4 \%$ implementor menyediakan dukungan dana dari pribadi. Beberapa alasan yang sempat penulis tanyakan kepada implementor tentang penyediaan sarana/fasilitas pendukung SIMPUSTRONIK oleh pribadi adalah kemanfaatan alat/sarana untuk dipergunakan aplikasi lainnya seperti mengetik laporan, internet, sosial media, games atau untuk keperluan anak/keluarga.

Faktor-faktor implementasi yang tidak mempunyai pengaruh adalah Pembagian tugas dan wewenang, keterlibatan pengguna dalam pengembangan implementasi dan keterlibatan pengguna dalam evaluasi implementasi terhadap baik dan tidaknya implementasi SIMPUSTRONIK.

Hal ini bisa dijelaskan bahwa implementor dalam hal ini Bidan masih berharap bahwa tugas pengentryan dan analisa SIMPUSTRONIK diserahkan pada petugas khusus. Mengingat begitu banyak beban pencatatan yang ditanggung mereka dan adanya setengah hati dalam penerapan SIMPUSTRONIK.

Secara deskriptif, kemanfaatan SIMPUSTRONIK bagi Bidan terbagi hampir merata 37,5\% menyatakan SIMPUSTRONIK kurang bermanfaat, 34,38\% menyatakan bermanfaat bahkan 2 orang $(6,25 \%)$ menyatakan sangat bermanfaat. Adapun kemanfaatan SIMPUSTRONIK untuk pelayanan KIA dinyatakan oleh para implementor bermanfaat sebanyak $62,5 \%$, sedangkan $37,5 \%$ menyatakan kurang bermanfaat. Sehingga dapat dikatakan bahwa SIMPUSTRONIK sebagian besar implementor 
telah menyatakan bermanfaat bagi pelayanan KIA.

Memperinci kemanfaatan SIMPUSTRONIK terutama dalam mendukung keberhasilan SPM program KIA didapatkan hasil sbb:

Kemanfaatan SIMPUSTRONIK bagi pencapaian kunjungan K4 dinyatakan kurang bermanfaat sebanyak 28,125\%, $37,5 \%$ cukup bermanfaat, $25 \%$ menyatakan bermanfaat bahkan 3,125\% menyatakan sangat bermanfaat.

- Kemanfaatan SIMPUSTRONIK bagi pencapaian persalinan nakes dinyatakan kurang bermanfaat sebanyak $6,25 \%$, cukup bermanfaat dinyatakan sebanyak $25 \%$ menyatakan bermanfaat $65,625 \%$, bahkan $3,125 \%$ menyatakan sangat bermanfaat

- Kemanfaatan SIMPUSTRONIK bagi pencapaian cakupan bumil resti yang dirujuk dinyatakan kurang bermanfaat sebanyak 6,25\%, cukup bermanfaat dinyatakan $46,9 \%$, menyatakan bermanfaat $40,6 \%$ bahkan $6,25 \%$ menyatakan sangat bermanfaat

- Kemanfaatan SIMPUSTRONIK bagi pencapaian cakupan kunjungan neonatus (KN2) dinyatakan kurang bermanfaat sebanyak 3,125\%\%, cukup bermanfaat dinyatakan $40,625 \%$, menyatakan bermanfaat $56,25 \%$

- Kemanfaatan SIMPUSTRONIK bagi pencapaian cakupan Kunjungan Bayi dinyatakan kurang bermanfaat sebanyak 9,375\% cukup bermanfaat dinyatakan $12,5 \%$, menyatakan bermanfaat $25 \%$

- Kemanfaatan SIMPUSTRONIK bagi pencapaian cakupan BBLR yang ditangani dinyatakan kurang bermanfaat sebanyak $9,375 \%$ cukup bermanfaat dinyatakan $12,5 \%$, menyatakan bermanfaat $25 \%$

- Hasil uji kemanfaatan SIMPUSTRONIK berpengaruh terhadap pelayanan KIA di Puskesmas Paiton diperoleh nilai uji Chi Square $=5.00 ;$ asymp sig $=0,25$ sehingga $\mathrm{H}_{0}$ ditolak. Adapun nilai koefisien kontingensinya $=0,021$ mempunyai arti berkorelasi sangat lemah.

- Hasil uji kemanfaatan SIMPUSTRONIK berpengaruh terhadap pelayanan KIA di Puskesmas Sumberasih diperoleh nilai uji Chi Square = 1,633; asymp sig $=0,201$ sehingga $\mathrm{H}_{0}$ ditolak. Adapun nilai koefisien kontingensinya $=0,296$ mempunyai arti berkorelasi sangat lemah.

Dari perhitungan diatas, nilai-nilai yang dicapai dapat digambarkan bahwa tidak ada perbedaan yang signifikan antara implementasi SIMPUSTRONIK di Puskesmas Paiton dengan implementasi SIMPUSTRONIK di Puskesmas Sumberasih.

\section{KESIMPULAN}

Berdasarkan hasil penelitian, deskripsi variabel dan pembahasan yang dilakukan, maka penelitian ini dapat disimpulkan sebagai berikut :

1. Dari 14 Faktor implementasi diteliti 11 yang mempunyai berpengaruh dengan implementasi SIMPUSTRONIK adapun 3 indikator yaitu pembagian tugas dan wewenang, keikutsertaan pengguna dalam pengembangan implementasi, dan keikutsertaan pengguna dalam evaluasi implementasi tidak mempunyai pengaruh pada pelaksanaan implementasi SIMPUSTRONIK.

2. Beberapa tanggapan responden dalam hal ini Bidan di wilayah kerja Puskesmas Sumberasih dan Puskesmas Paiton menyatakan bahwa implementasi SIMPUSTRONIK bermanfaat khususnya dalam pelayanan KIA.

3. Pengujian menunjukkan tidak adanya perbedaan implementasi SIMPUSTRONIK di Puskesmas Paiton maupun di Puskesmas Sumberasih meskipun dengan implementor yang berbeda.

Dengan pembuktian adanya kesamaan teori dan kenyataan di lapangan, serta kemanfaatan SIMPUSTRONIK, maka rekomendasi yang diberikan adalah bahwa SIMPUSTRONIK layak untuk di gunakan sebagai aplikasi Sistem Informasi Puskesmas, dan Penelitian terhadap implementasi SIMPUSTRONIK masih terbuka dengan semakin banyaknya pengguna.

\section{UCAPAN TERIMA KASIH}

Diucapkan terima kasih kepada Saudara Erwin HP dan Puguh yang telah membantu pelaksanaan penelitian ini. Dan juga terima kasih kepada Kepala Dinas Kesehatan Kabupaten Probolinggo, Kapala Puskesmas Sumberasih dan Kepala Puskesmas Paiton yang telah mengijinkan penelitian ini, serta untuk Prof. Dr Abdul Hakim, MSi dan DR. M Makmur, MS selaku pembimbing dalam penelitian ini disampaikan amat sangat terima kasih yang mendalam, karena telah membimbing dengan kesabaran dan pemberian motivasi yang diperlukan oleh penulis.

Dan tak lupa terima kasih yang setinggi-tingginya buat isteriku, anak-anakku serta ibu dan kakakku 
yang telah mendoakan, mendampingi dan berkorban demi kesuksesan penelitian ini.

\section{DAFTAR PUSTAKA}

[1]. Departemen Kesehatan RI, 2004. Keputusan Menteri Kesehatan Republik Indonesia Nomor 128/Menkes/SK/II/2004 Sistem Informasi Puskesmas (SIMPUS), Jakarta

[2]. Departemen Kesehatan RI, 1996, Pedoman Pemantauan Wilayah Setempat kesehatan Ibu dan Anak (PWS-KIA), Jakarta.

[3]. Departemen Kesehatan RI, 1996. Keputusan Direktur Jenderal Pembinaan Kesehatan Masyarakat Nomor: 590/BM/DJ/INFO/V/96 Tentang Penyderhanaan Sistem Pencatatan dan Pelaporan Terpadu Puskesmas (SP2TP).Jakarta

[4]. Dinas Kesehatan Kabupaten Probolinggo, 2010. Profil Kesehatan Tahun 2010, Probolinggo

[5]. Dinas Kesehatan Kabupaten Probolinggo, 2008. Rencana Strategis Dinas Kesehatan Kabupaten Probolinggo 2008 - 2013, Probolinggo

[6]. Dinas Kesehatan Kabupaten Probolinggo, 2010. Laporan Perkembangan SIMPUSTRONIK, Probolinggo

[7]. Grant, A., I. Plante dan F. Leblanc. 2002. The TEAM methodology for the evaluation of information systems in biomedicine. Computers in Biology and Medicine 32:195-207

[8]. Hamzah, A. 2009. Evaluasi Kesesuaian Model Keprilakuan Dalam Penggunaan Tekonologi Sistem Informasi di Indonesia. Paper read at Seminar Nasional Aplikasi Teknologi Informasi 2009 (SNATI 2009), at Yogyakarta..

[9]. Jogiyanto, H. M. dan W. Abdillah. 2009. Konsep dan Aplikasi PLS (Partial Least Square) Untuk Penelitian Empiris.: BPFE UGM Yogyakarta, Yogyakarta.

[10]. Kaplan, B 2001. Evaluating Informatics applications some alternative approaches: theory, social interactionism, and call for methodological pluralism. Internationa Journal of Medical Informatics 64:39-56

[11]. Kohn, L. T., J. M. Corrigan dan M. S. Donaldson. 1999. To err is human: Building a safer health system. Washington, DC: National Academy Press
[12]. Kristanto, E. 2007. Evaluasi Penerapan Sistem Informasi Manajemen Rumah Sakit di RSUP Dr. Sardjito Yogyakarta dengan menggunakan HOT-Fit, Tesis Magister Teknologi Informasi, Implementasi SIMPUSTRONIK Pascasarjana Universitas Gadjah Mada Yogyakarta.

[13]. Lee, T. T., M. E. Mills, B. Bausell dan M. H. Lu. 2008. Two-stage evaluation of the impact of a nursing information system in taiwan. International Journal of Medical Informatics 77:698-707

[14]. Mohammad, Ibrahim, 2001. Implementasi Kebijakan Pembangunan Prasarana Pendukung Desa Tertinggal (P3DT) Terhadap Pemberdayaan Masyarakat, Thesis, Magister Administrasi Negara, Program Pasca Sarjana Universitas Brawijaya Malang

[15]. Nasir, Mochamad, 2008. Pengembangan Sistem Informasi Pelayanan Kesehatan ibu Dan Bayi Untuk Mendukung Evaluasi Program Kesehatan Ibu Dan Anak (Kia) Di Puskesmas Kabupaten Lamongan, Magister Ilmu Kesehatan Masyarakat, Program Pasca Sarjana Universitas Diponegoro, Semarang.

[16]. Noor Azizah KS, M. dan J. M. Garibaldi. 2010. A Novel Evaluation Model of User Acceptance of Software Technology in Healthcare Sector Paper read at Proceeding of the 3rd International Joint Conference on Biomedical Engineering Systems and Technologies, at Valencia,Spain

[17]. Purba, E. L. 2007. Akseptansi dan Kepuasan Pengguna Sistem Informasi Rumah Sakit (SIRS) di Rumah Sakit Umum Daerah (RSUD) Pematang Siantar,Tesis Magister Teknologi Informasi, Pascasarjana Universitas Gadjah Mada, Universitas Gadjah Mada, Yogyakarta.

[18]. Radityo, D. dan Zulaikha. 2007. Pengujian Model DeLone and McLean Dalam Pengembangan Sistem Informasi Manajemen (Kajian Sebuah Kasus) In Simposium Nasional Akuntansi $X$. Universitas Hasanuddin Makassar

[19]. Singarimbun, Masri dan Sofian Effendi, 1995. Metode Penelitian Survei. PT Pustaka LP3ES Indonesia, Jakarta

[20]. Sudarianto. 2008. Evaluasi Penerapan Sistem Informasi Transaksi Puskesmas di Kabupaten Bantaeng Provinsi Sulawesi Selatan, Program Pasca Sarjana Fakultas Kedokteran Universitas Gajah Mada, Jogjakarta 
[21]. Tangkilisan, Hessel Nogi S., Drs., Msi., 2003. Implementasi Kebijakan Transformasi Pikiran George Edward, Limplementor SIMPSUTRONIKan Offset dan YPAP Indonesia, Yogyakarta

[22]. Tjokroamidjojo, Bintoro, 1979, Perencanaan Pembangunan, PT Gunung Agung, Jakarta.

[23]. Tjokrowinoto, Moeljarto, 1996, Pembangunan Dilema dan Tantangan, Pustaka Pelajar, Yogyakarta

[24]. Todaro, Michael P, 1989, Economic Development in The Third World (Fourth Edition), Longman, New York

[25]. Winarno, Budi, 2002. Teori dan Proses Kebijakan Publik, Media Pressindo, Yogyakarta

[26]. Yusof, M. M., J. Kuljis, A. Papzafeiropoulou dan L. K. Stergioulas. 2008. An evaluation framework for health information systems: human, organization and technology-fit factors (hot-fit). International Journal of Medical Informatics 77:386-398 